\title{
Commercial Strategies Providers Pharmaceutical Chains for Logistics Cost Reduction
}

\author{
Amelec Viloria* \\ Escuela de Negocios de la Fundación Universitaria Konrad Lorenz, Bogotá, Colombia; \\ amelecj.viloras@konradlorenz.edu.co
}

\begin{abstract}
Objectives: This Article aims to raise Strategies Commercial Provider Chains Pharmaceutical Abatement of their costs of logistics. Methods/Statistical analysis: The process was divided into four (4) phases Diagnosis, analyse, proposals e implementation. Findings: The first proposal is to increase the value of Minimum Order Value (MOV), which forces customers to pass orders greater value and volume generating more stock in their warehouses and therefore make fewer orders. This positively impacts the logistics department budget, given the savings generated in fixed administrative costs and transportation. The second option is a total restructuring of the business strategy, simplifying business conditions, normalizing discount rates, establishing new promotions, creating a bonus system that offers the customer different discount rates depending on the total order value, the influences the customer and brings it to place orders for larger volume, therefore less requested a year. Application/Improvements: This proposal seeks to simplify the logistics strategy and sales operations, reducing operating costs and incremental search business.
\end{abstract}

Keywords: Business Strategy Bid Order, Commercial Strategies, Supply Chain

\section{Introduction}

Every commercial organization aims to produce, so from that it goes aims to establish chains or business relationships that maximize their profits. To this end, market studies that demonstrate the specific situation of each sector, to thereby establish appropriate strategies should be made. In this sense, the pharmaceutical industry, offers a range of products that are of essential nature for humans, since they involve the strengthening or cure health client in this case is patient. So should view the levels of competitiveness of specific pharmaceutical organization to increase productivity by avoiding the fewest possible expenses.

\section{Theoretical Foundation}

Currently, high competitiveness, changes in markets and the financial crisis, generate great pressure on corporate managers. These are continually demanding their managers and employees make simplification or process reengineering, search for cost reduction and achieve profit maximization ${ }^{1}$.

Within the pharmacy channel in France, there is a big difference between all customers, from large pharmacies in major cities such as medium in residential areas or small farming villages. This generates a range of fairly large volumes of orders and the only existing restriction is the MOV. Thus arises the need to question the model 
and the current procedures, the main approach is to find a method to induce customers to spend less purchase orders, without generating a financial impact $2 \frac{2,3}{3}$.

Business strategies and business conditions of the company under study are clearly defined. These are based on the signing of contracts between the company and pharmacies, which offer discounts and benefits specific category. At the beginning of the contract in which the pharmacy is committed to making a certain volume of sales is established, which results in different levels of discount promotions and other conditions that benefit the customer.

However, constantly changing conditions are made, new categories are added to the product portfolio or new developments are set. Which leads to continuous changes in information systems, greater complexity in the monitoring of logistics operations, increased chances of error in billing, among other issues, generating an increase in operating costs?

Therefore, in this research they are designed and implemented trading strategies that allow the company to reduce study costs, specifically those related to logistics and continue driving the growth of trade.

\section{Methodology}

The proposed methodology is defined by the following phases ${ }^{4}$ :

- Diagnose the current management of the supply chain in the circuit of pharmacies, their business models and their overall impact on business management.

- Analyze the current business strategy of the chain of pharmaceutical products supplier.

- Propose business strategies for the chain of pharmaceutical products supplier.

- Implement and evaluate strategies proposed.

\section{Results and Discussion}

\subsection{Phase 1: Diagnosis of Supply Chain and Business Model}

Below it is presented in Table 1. Strengths, Weaknesses, Opportunities, And Threats (SWOT) matrix supply chain provider of pharmaceutical products.
Table 1. SWOT matrix for supply chain provider

\begin{tabular}{|l|l|}
\hline STRENGTHS & OPPORTUNITIES \\
\hline $\begin{array}{l}\text { - Partnerships With } \\
\text { customers }\end{array}$ & $\begin{array}{l}\text { - Simplification of business } \\
\text { conditions } \\
\text { structured } \\
\text { better integration of information } \\
\text { systems } \\
\text { - Trademarks With } \\
\text { market positioning }\end{array}$ \\
\hline WEAKNESSES & - Improvements Logistics \\
\hline $\begin{array}{l}\text { - Complexity of } \\
\text { business strategy and } \\
\text { logistics operations } \\
\text { - Failures in internal } \\
\text { communication }\end{array}$ & $\begin{array}{l}\text { - Competition with better and } \\
\text { simpler trading conditions. }\end{array}$ \\
\hline
\end{tabular}

\subsection{Phase 2: Analysis of Business Strategy}

Table 2. shows the SWOT matrix for the commercial strategy currently applied by the company under study is identified.

Table 2. SWOT matrix for the current marketing strategy supplier ${ }^{5,6}$

\begin{tabular}{|l|l|}
\hline STRENGTHS & OPPORTUNITIES \\
\hline $\begin{array}{l}\text {-Strategy Known by } \\
\text { customers } \\
\text {-Configured in information } \\
\text { systems }\end{array}$ & $\begin{array}{l}\text {-Ability To vary the MOV } \\
\text { and development of new } \\
\text { discounts }\end{array}$ \\
\hline WEAKNESSES & THREATS \\
\hline $\begin{array}{l}\text {-Arrival Of new categories } \\
\text {-MOV low } \\
\text {-dependent Information system }\end{array}$ & $\begin{array}{l}\text {-Risk Financial changes } \\
\text {-Resistance To change by } \\
\text { force sale }\end{array}$ \\
\hline
\end{tabular}

\subsection{Phase 3: Proposed Business Strategies}

The proposals of changes in MOV indicator and improvements in business strategy are developed.

\subsubsection{Strategy 1: Changes in MOV Indicator}

It is planned to observe the possible scenarios that can be obtained by increasing or decreasing this value. The main objective of this proposal is to seek savings in total billing costs by reducing the number of annual orders and alignment with business growth objectives. The two basic scenarios are decreasing or increasing this value. 
In the case of a decrease, this allows the search for new small customers who have no ability to make large orders. While this generates sales growth, a direct increase in costs is because the amount of orders from both new customers and old who prefer to make small orders to reduce their inventories in pharmacies increases.

The scenario of increasing MOV, would force customers to spend more orders volume and value. In this case, you are taking a push strategy so inventories will be increased customers. Therefore, it is assumed that occur a reduction in purchase orders. Similarly one should consider the potential loss of business or profit impact, customers are not willing or able to adapt to increased MOV.

\subsubsection{Strategy 2: Improved Business Strategy}

The proposal that develops is the simplification of current business strategy, by eliminating the markets and condition ${ }^{4}$. The proposes to establish a basis for category discount, which will be offered to all customers. To complement customer's additional discounts and promotions by category or subcategory, depending on the volume of units engaged in the order is made ${ }^{5,7}$.

Totalization of the order value is then performed and to encourage customers to make higher - value orders, an additional discount on the total turnover is offered. Orders will be classified in ranges of value, as the range increases to increase the discount offered. This tool can also be seen as a push strategy will allow reduction in orders requiring the customer during the year and therefore a reduction in operating costs.

\subsection{Phase 4: Evaluation and Validation of Proposals}

By varying the parameters of the models may have different simulation scenarios using Excel for the distribution chain of pharmaceuticals in the study. Only the best results shown in this phase Table 3. shows the results of calculating the impact on revenue due to increased MOV is presented. It was considered that the value ranges between 0 to 200,200 to 300 , 300 to 400 euros, an impact of thirty percent (30\%), ten percent $(10 \%)$ and five percent $(5 \%)$ is generated respectively.
Table 3. Impact calculation of income by establishing a MOV to $400 €$

\begin{tabular}{|l|c|c|c|c|}
\hline Rank & $\begin{array}{c}\text { No. } \\
\text { invoice }\end{array}$ & $\begin{array}{c}\text { Income } \\
\text { (euros) }\end{array}$ & \% impact & $\begin{array}{c}\text { Impact } \\
\text { (euros) }\end{array}$ \\
\hline $0-200$ & 8849 & 1531811.54 & 30 & 459543.46 \\
\hline $200-300$ & 8826 & 2.256 .67859 & 10 & 225667.86 \\
\hline $300-400$ & 6127 & 2198909.18 & 5 & 109945.46 \\
\hline \multicolumn{5}{|c|}{ Total impact } \\
\hline
\end{tabular}

In Table 4 and Table 5 the results obtained with defined discount rates are presented. Estimates used to determine which can be earned approximately four thousand five hundred $(4,500)$ purchase orders, representing a saving of some twenty thousand euros $(20,000$ $€)$. The marketing and sales department must locate a budget about seven hundred forty thousand euros ( $€$ $740,000)$

Table 4. Evaluation invoice discount depending on the value range

\begin{tabular}{|l|c|c|c|}
\hline Ranges & $\begin{array}{c}\text { Discount rate } \\
\%\end{array}$ & $\begin{array}{c}\text { \% Reduction } \\
\text { in orders }\end{array}$ & $\begin{array}{c}\text { Order } \\
\text { less }\end{array}$ \\
\hline $150-500$ & 0 & 20 & 4978 \\
\hline $500-1000$ & 1 & 15 & 2411 \\
\hline $1000-2500$ & 1,5 & 5 & 570 \\
\hline $2500-5000$ & 2 & 2 & 52 \\
\hline 5000 -máx & 2,5 & 0 & 0 \\
\hline
\end{tabular}

\section{Conclusions}

Table 3 it can be seen that increasing the MOV to four hundred euros $(400 €)$ a reduction of approximately forty-five percent (45\%) of the purchase orders is done. Which allows the supplier to make a saving of around forty-eight thousand euros $(€ 48,000)$ in billing expenses, which is for them the most critical budget? Equally significant savings are made in transport costs. Although you should take precautions with the impact on income of about eight hundred thousand euros ( $€$ $800,000)$ representing thirteen percent $(13 \%)$ of lower revenues to MOV. 
Table 5. Evaluation invoice discount depending on the value range

\begin{tabular}{|c|c|c|c|c|}
\hline Ranges & $\begin{array}{l}\text { Entry } \\
\text { (Euros) }\end{array}$ & \# Order & $\begin{array}{l}\text { Income undiscounted } \\
\text { (Euros) }\end{array}$ & $\begin{array}{l}\text { Income Discount } \\
\text { (Euros) }\end{array}$ \\
\hline & $1.452 .914,35$ & 19910 & $5.811 .657,40$ & $5.811 .657,40$ \\
\hline $500-1000$ & $1.709 .770,42$ & 15711 & $11.141 .613,42$ & $11.030 .197,29$ \\
\hline $1000-2500$ & $861.868,53$ & 11963 & $18.085 .272,49$ & $17.813 .993,40$ \\
\hline $2500-5000$ & $174.249,57$ & 2817 & $9.400 .097,52$ & $9.212 .095,57$ \\
\hline 5000-máx & - & 780 & $6.717 .485,71$ & $6.549 .548,57$ \\
\hline Won orders & 4553 & Total discount & \multicolumn{2}{|c|}{$738.634,31$} \\
\hline Cost / Order & 4,45 & & & \\
\hline Budget won & $20.259,17$ & & & \\
\hline
\end{tabular}

Analyzing the Table 4 and Table 5 it can be concluded that the sales and marketing department of the supplier must locate a budget about seven hundred forty thousand euros $(€ 740,000)$. This can be considered as a great impact, but you should consider it off is associated with streamlining business strategies. Therefore the marketing and sales department must perform the calculations necessary to adapt this discount along with discounts and promotions basis.

\section{References}

1. Metzger M, Donaire V. Strategic marketing management. Mexico: International Thomson Publishing; 2007.

2. P \& G Pharmaceuticals. The power of purpose [Internet]. 2016 [cited 2016 Feb]. Available from: http://www.pg.com/ en_US/company/purpose_people/index.shtml.
3. Sainz JM. Commercial distribution: strategic options. Madrid, Spain: ESIC Editorial; 2011.

4. Schultz, Robinson W. As direct the promotion of their sales. Barcelona, Spain: Ediciones Granica SA Soret, I. Madrid, Spain: ESIC Editorial; 2006.

5. Amelec V. Validation of strategies to reduce exhausted shelf products in a pharmaceutical chain. Advanced Science Letters. 2015 May; 21(5):1403-5.

6. Amelec V. Increased efficiency in a company of development of technological solutions in the areas commercial and of consultancy. Advanced Science Letters. 2015 May; 21(5):1406-8.

7. Amelec V. Validation process container for distribution of articles for home. Advanced Science Letters. 2015 May; 21(5):1413-5. 